\title{
Evolution of a Junction Traffic Management Measures Using Microsimulation Model
}

\author{
Osman Ünsal BAYRAK ${ }^{1}$, Halim Ferit BAYATA², Fatih HATTATOĞLU ${ }^{1}$, Muhammet Ali ÇOLAK ${ }^{2}$
}

\begin{abstract}
Travel efficiency and traffic safety of unsignalized intersections are two main objectives considered in traffic management. Microscopic simulations are widely used in transportation operations and management analysis because "simulation is safer, less expensive and faster than field implementation and testing". VISSIM is a microscopic traffic simulation program. The heaviest traffic volume and annually average 15 accidents occurred in Atatürk University campus that connect Çat Road to Hospital named as Teknokent Junction was studied. Field observations were simulated in VISSIM. Signalization program and geometric changes were proposed and applied in the field. After the application, no traffic accident was observed in the junction for 1,5 years. Applied right turn island minimized the delay time for the arms.
\end{abstract}

Keywords: Junction, microsimulation, traffic accident, traffic management, VISSIM

\section{Mikrosimülasyon Kullanılarak Bir Kavşağın Trafik Yönetim Ölçümlerinin Değerlendirilmesi}

ÖZET: Trafik yönetiminde ele alınan iki ana amaç sinyalize olmayan kavşaklardaki trafik güvenliği ve yolculuk verimliliğidir. Mikroskopik simülasyonlar ulaşım projelerinde ve yönetiminde yaygın bir şekilde kullanılmaktadırlar çünkü simülasyon güvenlidir daha ekonomiktir ve arazi uygulama ve denemelerinden daha hızlıdır. Bu çalışmada Atatürk Üniversitesi Kampüsündeki en yoğun trafik hacmine sahip ve yıllık ortalama 15 kazanın olduğu Teknokent Kavşağ 1 incelenmiştir. Araziden elde edilen ölçümler VISSIM programı ile simüle edilmiştir. Farklı sinyal programları ve geometrik düzenlemeler önerilmiş ve uygulanmıştır. Uygulamalardan sonra ilgili kavşakta 1,5 yıldır herhangi bir kaza olmamıştır. Önerilen ve uygulanan sağa dönüş adaları kollardaki gecikmeleri minimize etmiştir.

Anahtar Kelimeler: Kavşak, mikrosimülasyon, trafik kazaları, trafik yönetimi, VISSIM

Atatürk Üniversitesi, Mühendislik Fakültesi, İnşaat Mühendisliği, Erzurum, Türkiye

Erzincan Üniversitesi, Mühendislik Fakültesi, İnşaat Mühendisliği, Erzincan, Türkiye

eSorumlu yazar/Corresponding Author: Osman Ünsal Bayrak, oubayrak@atauni.edu.tr 


\section{INTRODUCTION}

Comfort and safety are two primary goals of transportation engineering. Traffic accidents are one of the leading causes of injuries in Turkey. The public agencies are working intensively to reduce the accidents and traffic accidents placing a huge financial burden on society (Abdel-Aty and Radwan, 2000). There are two major factors usually playing an important role in traffic accident occurrence. The first is related to the driver and the second is related to the roadway design (Peden, 2004). The junction geometry and signalization should be investigated for the roadway design to traffic accident (Golias, 1997).

Data traffic collection and analysis are extensively required by traffic engineers for traffic control and management (Fathy and Siyal, 1997). Modern urban areas are witnessing increasing traffic congestion due to high car ownership rates and a strong dependency on private cars. Junctions often pose the main bottleneck in urban traffic networks resulting in capacity flow on the network links and excessive delays. A continuous expansion of the infrastructure cannot remain as the go-to solution to these problems due to land-use, environmental and financial limitations. An alternative is the use of traffic control strategies that are adaptable to prevailing traffic conditions. Such methods can provide a safe and feasible solution to traffic congestion problems through the efficient and intelligent use of the network (Aw and Rascle, 2000).

Traffic management is the term used to describe a wide range of technical practices undertaken to manage the traffic across networks, which include prioritization, slowing down (Shankar et al., 2013). As the number of vehicles and pedestrians grow, the roads which were designed long time ago remain the same. Area traffic management contains a process and a set of measures used to ensure that the streets within neighborhoods are used appropriately.

There are different active traffic management techniques such as Speed Harmonization, Queue Warning, Junction Control, Hard Shoulder Running, Dynamic Rerouting and Travel Time Signs (Abdel-Aty et al., 2010). Each of them has several benefits such as maintaining flow and reducing risk of collisions, effective utilization of available roadway capacity and reduction of the likelihood of the speed differentials and collisions related to queuing, effective utilization of available roadway capacity and management of traffic flows to reduce the congestion, minimization of recurrent congestion and managing the traffic during incidents, effective utilization of available roadway capacity by redirecting traffic to less congested facilities, allowing better en-route decisions by travelers. Gladys (2009) observed that traffic management measures are usually evaluated by using Moving Car Surveys to get data on journey time, journey speeds, time spent when stopped, time spent when delayed, and as a proxy for fuel consumption, the number of stops for vehicles (Shankar et al., 2013). Flaherty has observed that regulatory traffic management has its basis in law, and uses mandatory and prohibitory traffic signs and markings to inform drivers regarding what they must and must not do in relation to speed, movement and waiting (Flaherty, 2000).

Microscopic simulations are widely used in transportation operations and management analysis because "simulation is safer, less expensive and faster than field implementation and testing" (Park and Schneeberger, 2003; Burghout and Wahstedt, 2007; Truong et al., 2015). It is a useful tool to effectively analyses and evaluate the proposed improvements and alternatives. For instance, an intersection can be simulated for different signal timing plans, changing geometries of the junction, different peak hour volumes and its effects found before implementing it.

Simulation models are widely used to analyze the traffic networks in different modes of transportation and various general or specialized simulation packages have been employed. In the past years, microsimulation techniques have been used widely by transportation researchers to evaluate and compare the operational performance of design alternatives. (Gomes et al., 2004; Laufer, 2007; Hollander and Liu, 2008; El Esawey and Sayed, 2011). Microsimulation models include variable behavior of drivers at a level of each particular entity, and the reality of modelling results depends on the initial choice of the model and success of the calibration process (Ištoka Otković et al., 2013). Recently, some studies have confirmed that the reproduction by simulation of user behaviour under different flow and geometric conditions can identify a potential incident hazard and allow to 
take appropriate counter measures at specific points of the road network (Cunto and Saccomanno, 2007; Cunto and Saccomanno, 2008; Saccomanno et al., 2008). Microscopic traffic simulators are probably the most powerful and versatile traffic analysis tools for individual vehicle movements along roads and through junctions in a network (Bell et al., 2012). Several traffic microsimulation models such as VISSIM, PARAMICS and AIMSUN provide an opportunity to assess the impact of transit signal priority (Stevanovic et al., 2008).

VISSIM is a microscopic multimodal traffic simulation model. It can assign behaviour to individual vehicles as they circulate from their origin to their destination (Martínez et al., 2011; Sun et al., 2013). Furthermore, most of the macroscopic features can also be analysed because of the microscopic rules calibration. Besides, different transportation modes and their interactions can be modelled (García et al., 2011). VISSIM can be applied to multiple scenarios such as mobility studies, intelligent traffic systems, traffic management and control systems (Fellendorf and Vortisch, 2001). Brain et al. (2007) compared VISSIM and other simulation models. It was observed that VISSIM is more efficient in modelling the interaction of various modes of transit with automobile traffic (Shankar et al., 2013).

The objective of the study is to manage the Teknokent junction with measures to be implemented in the study area. Unsignalized Teknokent junction was modelled by microsimulation program, VISSIM. In the present model, signalization program and right turn island is proposed for the junction.

\section{MATERIAL AND METHOD}

\section{Study Area}

Ataturk University located in Erzurum in the east of Turkey is a campus with about 2 million $\mathrm{m}^{2}$ campus area. The study area which has the heaviest traffic volume in campus that connects Çat Road to Hospital named as Teknokent Junction was selected as shown in Figure 1. The traffic volume is established from the vehicles both coming to campus faculties and hospital. This junction was a typical four arm intersection with two lanes per direction on the main and two lanes each way on the secondary road. Teknokent junction, which has 4 unsignalized arms, serves heavy volume during the peak hours. The Çat Road to Hospital connection is very intensive in morning peak hours and the Dorm to Pharmacy Faculty connection is very intensive in evening peak hours. Generally the traffic congestion occurs during working hours, working out hours and hospital opening and closing hours. Although there is no park restriction on the Teknokent Junction, there is no parking around the junction. The traffic composition is composed highly of public transportation and cars. Because of this, junction was not signalized, there were annually 15 traffic accidents occurred. Although the traffic volume of the junction during morning peak hour and evening peak hour are different, the most intensive route has averagely 1000 - 1500 vehicles per hour. High congestion, lack of safety and traffic accidents were observed at Teknokent junction.

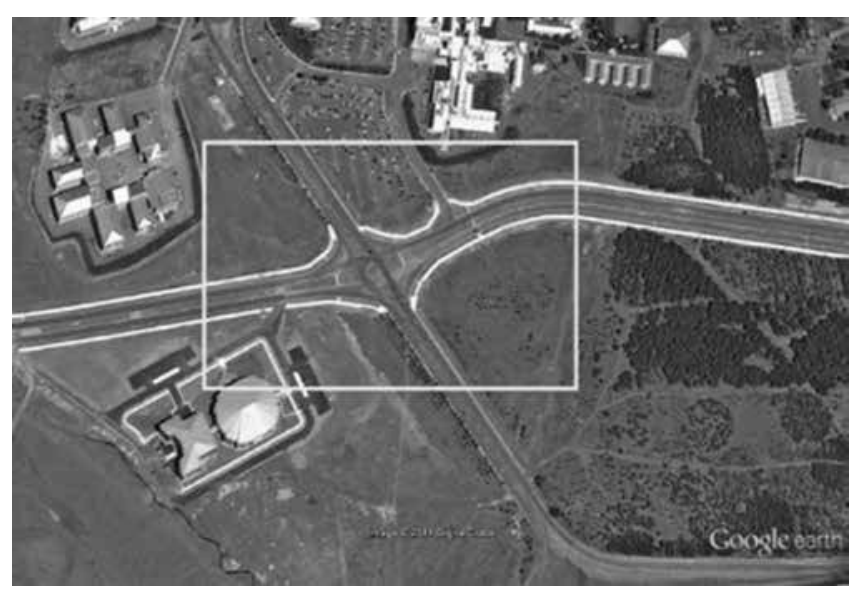

Figure 1. Study Area

\section{Data Collection and Analysis}

Traffic data collection and analysis is widely required by traffic engineers for traffic control and management. Various preliminary investigations, road and public transport inventories, traffic volume counts, intersection traffic volume counts, speed and delay studies were conducted in the network area during morning and evening peak hours. Once data collection was done, data were analyzed and modal split graphs, frequency of vehicles have been found. These outputs were used as input data in the micro simulation software VISSIM. 
The analysis of traffic flow at the signalized intersection was recognized as one of the most important concerns faced by the traffic engineering profession, since the amount of delay that occur at such intersections can render an otherwise excellent highway design inadequate. Estimating and developing means of avoiding vehicular delay at signalized intersection is a problem that is particularly well suited to queuing analysis techniques. Hence, traffic engineers have valuable analytic methods available to arrive at efficient signal designs at intersections.

Data was gathered, during 2014, at Teknokent junction by means of one-hour video camera recordings (Figure 2 and 3).

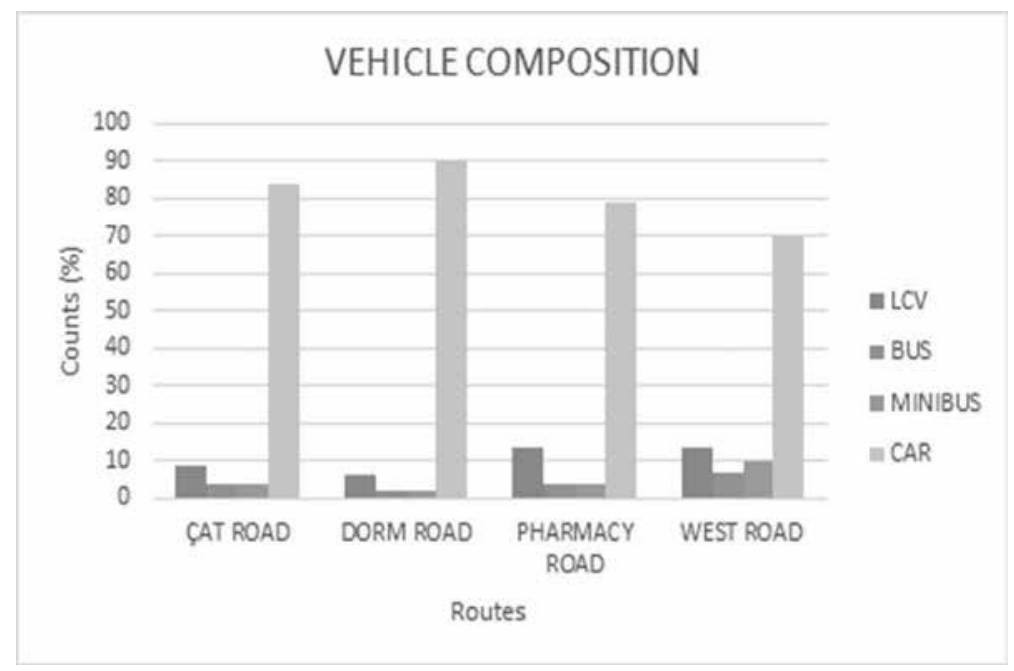

Figure 2. Vehicle Composition of the Junction for All Arms

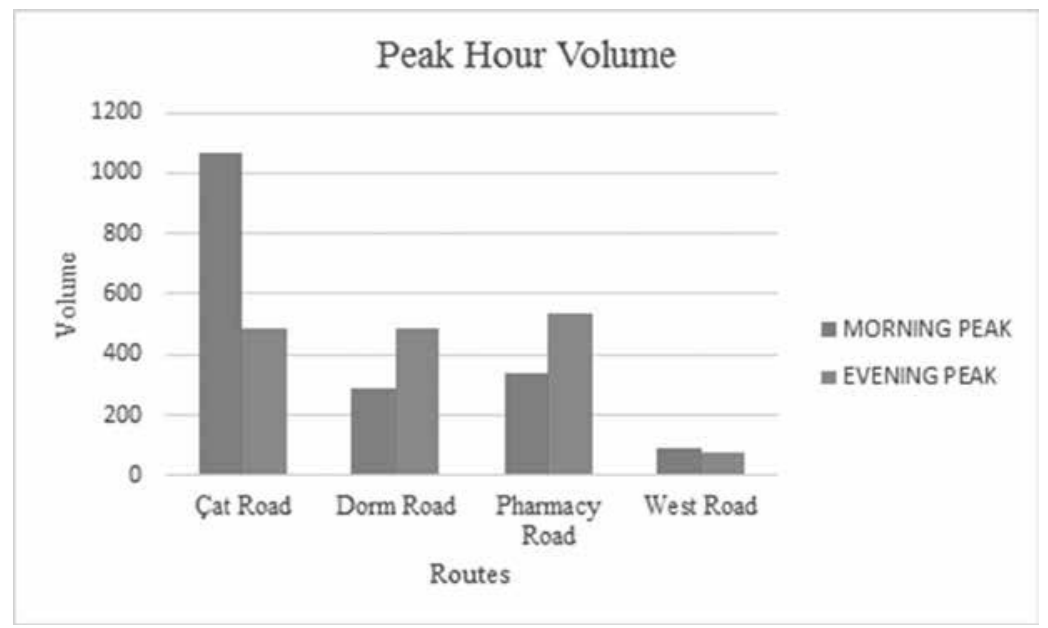

Figure 3. Peak Hour Volumes for Morning and Evening

High volumes are found between Çat Road and Pharmacy Road route for morning peak and also Pharmacy Road and Çat Road for evening peak. Cars, lightweight commercial vehicles (LCV), contribute to higher percentage of the modal share with an average of $80 \%$ cars and $11 \%$ LCV. After the physical inventory, few measures like junction control, signalization of intersection, routing, roundabout, right turn islands and U-turn were found to be adaptable for the study area.

Transportation area was modelled in VISSIM. This data along with the traffic data helps to understand the deficiencies in the existing capacity with an effort 
to address the need and requirements of the existing demand. These details were prepared using the image from Google maps as background.

Travel time and queue length characteristics along the critical road sections of the area were collected by the experts. This data provides the basis for better understanding and identifying the traffic bottlenecks in the routes.

\section{Model Development and Calibration}

After the data collection and analysis, a model is developed according to the field conditions. Volume at peak hour, modal split, road inventory of the study area are the inputs required. Once the model is developed, it is very important to calibrate the model for reliable results. In this model Geoffrey E. Havers (GEH) formula was used for volume calibration (Shankar et al., 2013). The volumes from model can be obtained using data collection point parameter in VISSIM.

Havers developed a continuous volume tolerance formula. Although its mathematical form is similar to a chi-squared test, it is not a true statistical test. Rather, it is an empirical formula that has been proven useful for a variety of traffic analysis purposes (de Dios Ortuzar and Willumsen, 1994). The network is said to be calibrated if the GEH value obtained from the formula is less than 5 for $85 \%$ of the links and GEH $<4$ for sum of all link counts. After the model is calibrated, simulation is run to find the deficiencies in the model in terms of high queue lengths, higher travel times, more number of stops, higher delays and stopped delays.

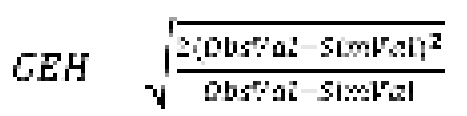

Here:

ObsVal : Observed value obtained from field

SimVal : Simulation value

The study junction was unsignalized and unorganized (Figure 4), hence there were so many conflicts between the arms. There was annually an average of 15 accidents per year. Vehicle composition of the junction for all arms and peak hour volumes for morning and evening in the Teknokent Junction was shown in Figure 2 and 3. In the study area, Çat Road is the most intensive arm of the junction and an average of 1064 vehicles pass through this arm during the morning peak hour (07:30 - 08:30). Further, approximately 450- 550 vehicles pass through Çat Road, Dorm Road and Pharmacy Road in the evening peak hour (16:00 17:00).

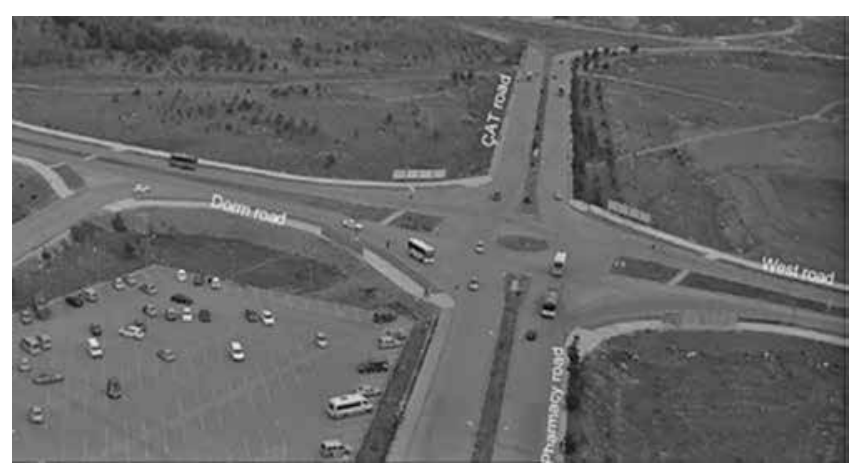

Figure 4. Unsignalized Teknokent Junction

Safety performance measures can be obtained either through simulation (based on well specified or calibrated traffic models) or experimentally through observational vehicle tracking data. Accurate calibration of the traffic models ensures that simulated measures of safety performance are reflective of the "real world" traffic conditions. The microscopic model, for a case study, allows the estimation of road safety performance through a series of indicators, representing interactions in real time between different pairs of vehicles belonging to the traffic stream (Guido et al., 2011).

Only travel time was measured at unsignalized junction for all arms. Queue length, number of stops and delay could not be measured due to unsignalized junction. Moreover, vehicles were stopped in the conflict area between the links. The vehicles coming from Çat Road had very high speed. Therefore, traffic accidents occurred in this intersection points. These accidents occurred in the intersection point between Çat Road and Dorm Road according to accident records.

Firstly, roundabout type junction (radius is greater than $21 \mathrm{~m}$ ) was planned for this junction. However, the land use of the area is limited for roundabout application, because the elevations of the arms of junction are so different from ground to applicate roundabout. The area needs a high landfill for roundabout. Hence, it was neither an economical nor a rapid solution. 
Secondly, the intersections were proposed to be made signalized. Signalized junction was planned and simulated by VISSIM for the junction. Travel time, delay and queue length were used as performance criteria. Two right turn islands were established in the model for Çat Road to Dorm Road and Pharmacy Road to West Road connection as seen in Figure 5. Further, U-turn area was created for the vehicles on Dorm Road before they reach the junction (Figure 5).

The signalization was applied to each arm and inner side of the junction (Figure 6). The reason for the application of inner signalization was the driving behaviour of Turkey, because, drivers in Turkey pass at the end of the amber and during the first second of the red time. Hence, there was a conflict between the cars passed during green and the cars turned left. Six signal groups were allowed for the junction given in Figure 6. Signal times and phasing were determined as several alternatives (Figure 6 - 7).

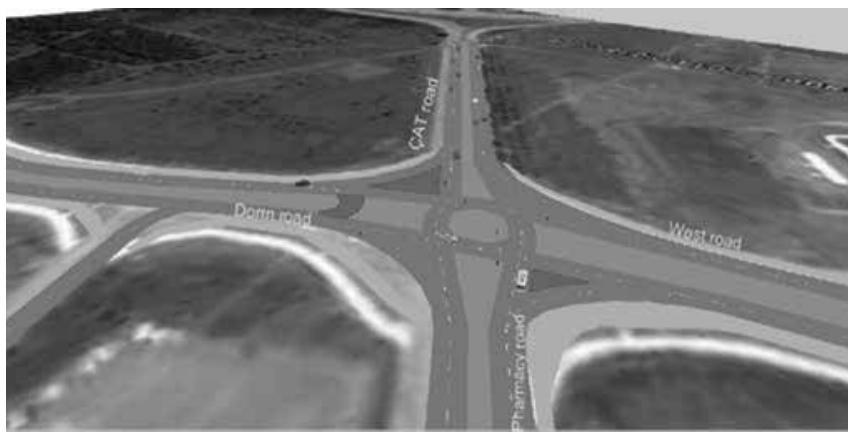

Figure 5. Established Model for Teknokent Junction

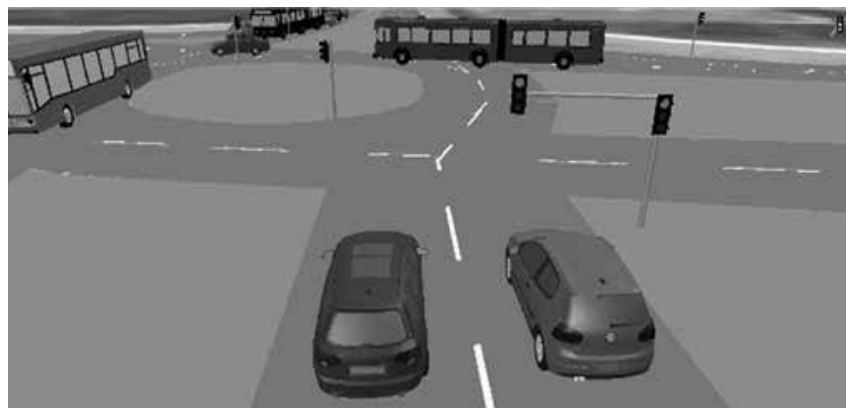

Figure 6. Signalization at Teknokent junction for Çat Road arm

Two different signalization programs were held in the morning and evening hour, because there was a big

difference in the number of vehicles in the morning and evening hours, especially on the Çat Road.

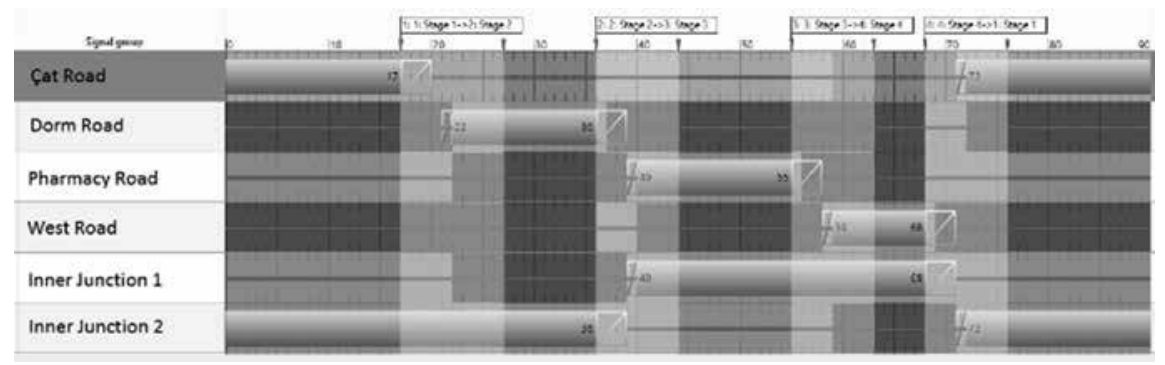

Figure 7. Signal Times for Evening Peak

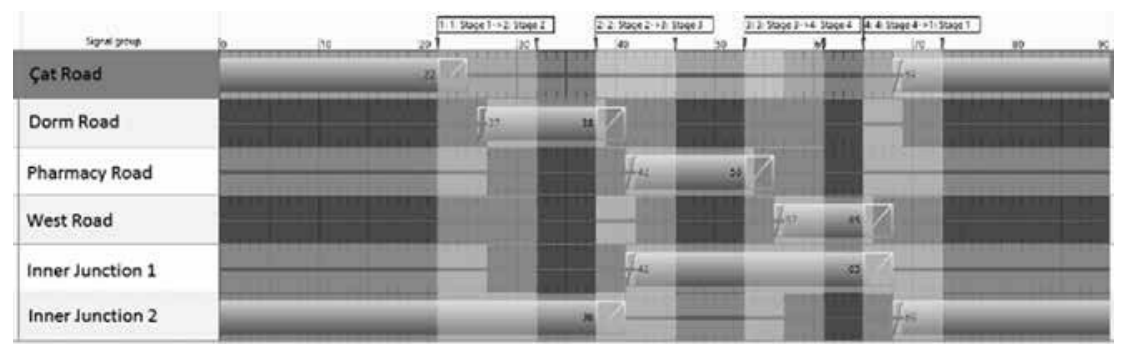

Figure 8. Signal Times for Morning Peak

\section{RESULTS AND DISCUSSION}

Calibration details were given in Table 1. After the model is calibrated, simulation is run to find the deficiencies in the model in terms of high queue lengths, average travel times and higher delays. 
Table 1. Calibration Details of the Vissim Model

\begin{tabular}{|c|c|c|c|c|c|c|}
\hline \multirow[b]{2}{*}{ Name of the route } & \multicolumn{3}{|c|}{ Travel Time (s) } & \multicolumn{3}{|c|}{ Queue Length (m) } \\
\hline & 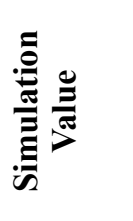 & 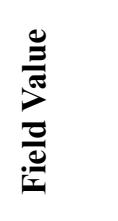 & 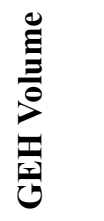 & 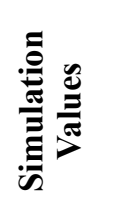 & 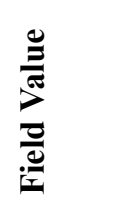 & 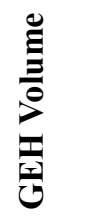 \\
\hline $\begin{array}{l}\text { Çat Road to Pharmacy Road } \\
\text { (Morning Peak) }\end{array}$ & 55.37 & 75.50 & 2 & 56.09 & 70.37 & 2 \\
\hline $\begin{array}{l}\text { Çat Road to Pharmacy Road } \\
\text { (Evening Peak) }\end{array}$ & 53.80 & 60.50 & 1 & 24.66 & 25.58 & 0 \\
\hline $\begin{array}{l}\text { Dorm Road to } \\
\text { West Road }\end{array}$ & 90.69 & 99.50 & 1 & 26.15 & 36.6 & 2 \\
\hline $\begin{array}{l}\text { Pharmacy Road to } \\
\text { Çat Road }\end{array}$ & 74.80 & 84.00 & 1 & 32.86 & 40.32 & 1 \\
\hline Total links & 274.66 & 319.50 & $3(<4)$ & 139.76 & 172.87 & $3(<4)$ \\
\hline
\end{tabular}

Table 1 shows the GEH values for the routes. According to Table 1, GEH values are smaller than 4 for the sum of all link counts. Hence the model is said to be calibrated.

The travel times, queue lengths and delays were evaluated for the implementation of traffic management measures. Because of the fact that two different signalization programs were used, the measures were obtained for morning and evening.

The proposed junction management model was established in the study area (Figure 9-10). Real time measurements of the performance criteria parameters were obtained. Real time measurements were compared with the simulation results, as seen in Table 1.

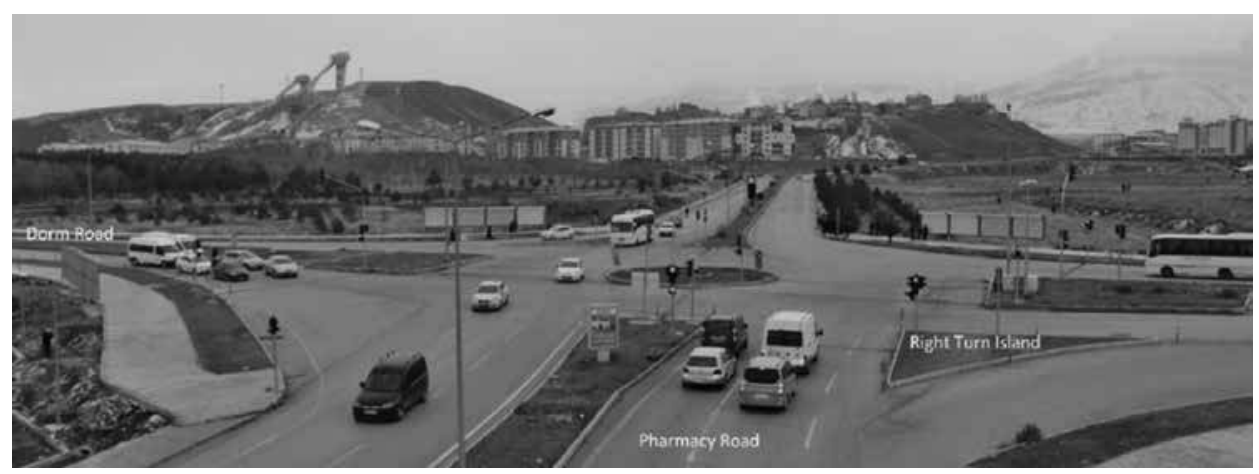

Figure 9. Right Turn Island for Pharmacy to West Road Route And Signalization Application

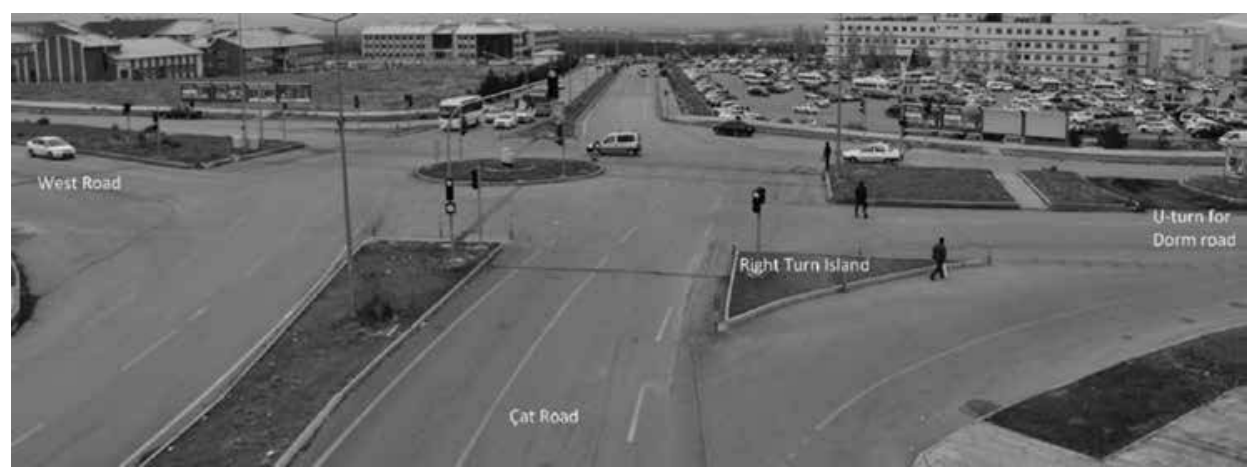

Figure 10. Right turn island for Çat to Dorm Road route and U-turn for Dorm Road 


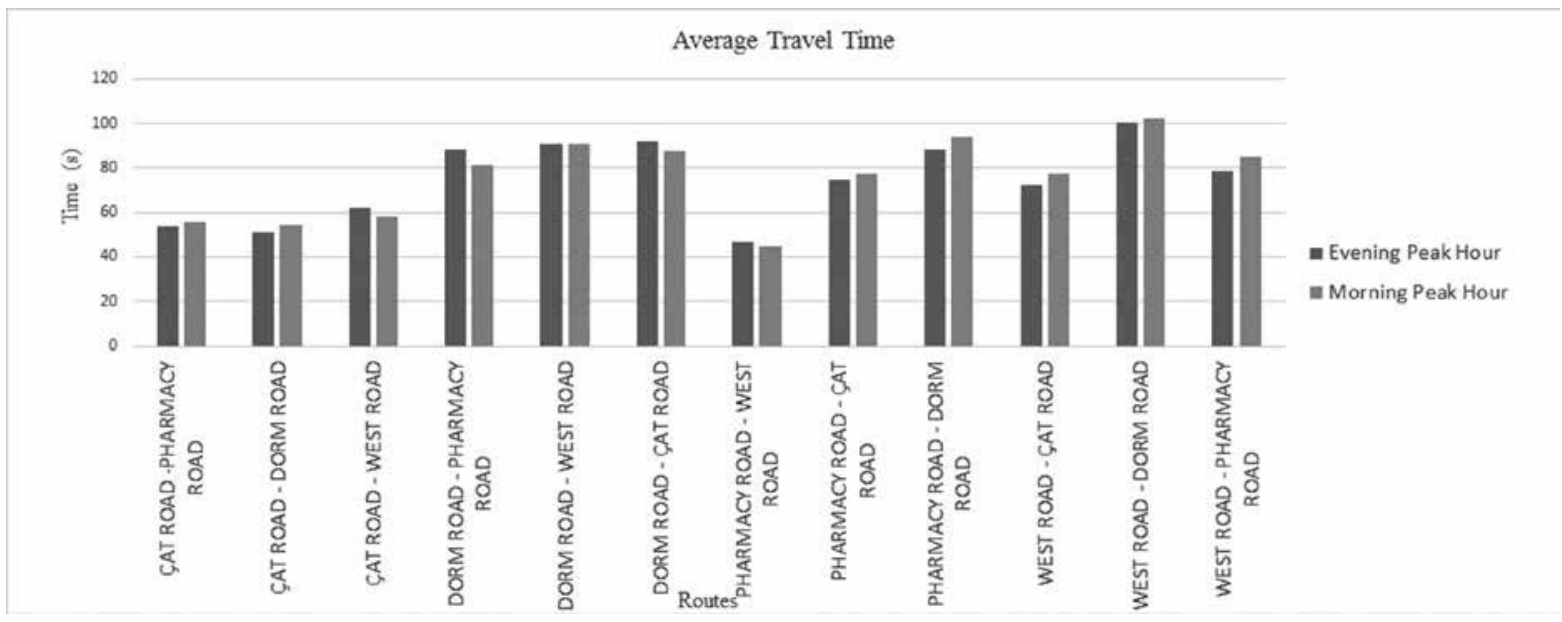

Figure 11. Travel Time for Morning and Evening Peak

In terms of travel time, similar periods of time were obtained depending on the morning and evening peak hours (Figure 11). Although the number of vehicles in traffic in the morning and evening is different, the travel time was not increased due to two different signal programs. For the travel time calculations, the route lengths were $590 \mathrm{~m}$ and $795 \mathrm{~m}$ for Çat Road and Dorm Road, respectively. Maximum travel time was observed from West Road to Dorm Road.

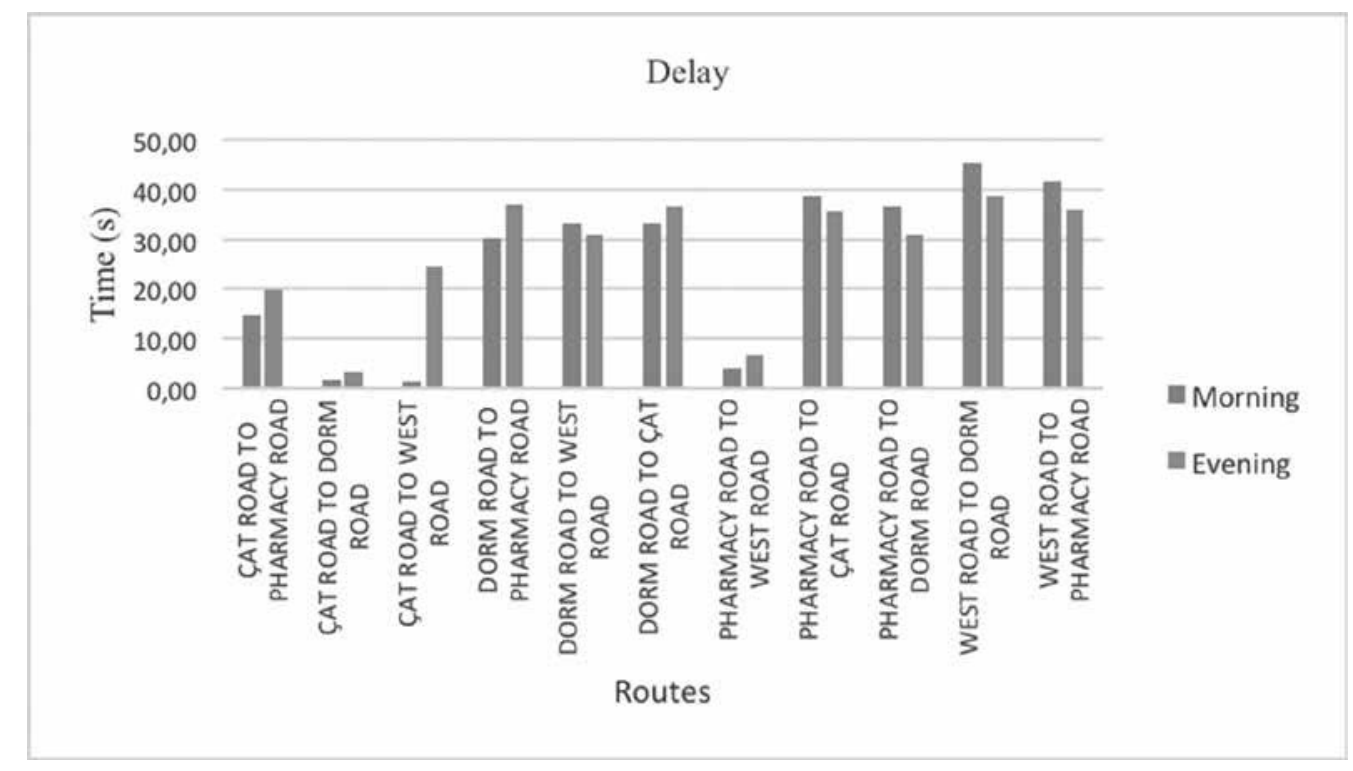

Figure 12. Average Delay for Morning and Evening Peak

In Figure 12, maximum delay values were determined on the West Road to Dorm Road route, because the longest red signal period was in this arm. The delay values were similar in morning and evening peak hour. The delay time was greater in the arms that have greater vehicle density, i.e. Çat Road and Pharmacy Road. By designing a right turn island on Çat Road to Dorm Road and Pharmacy Road to West, delay time was minimized. 


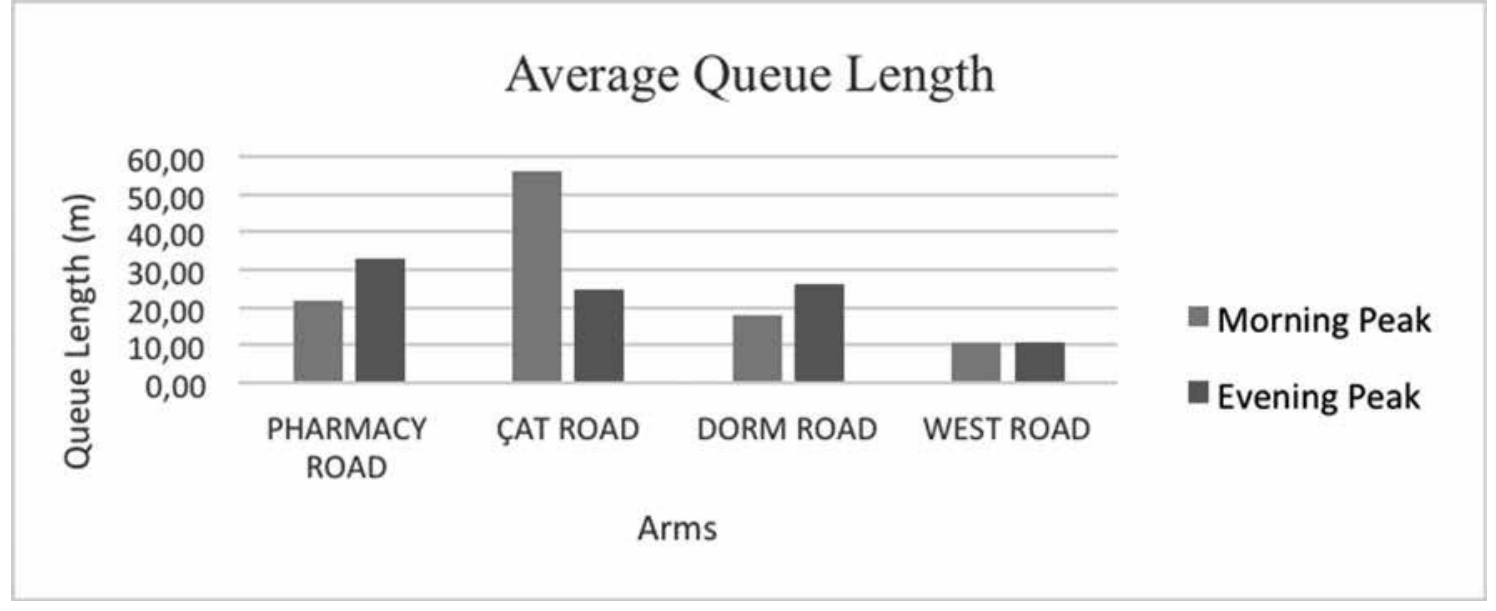

Figure 13. Queue Length for Morning and Evening Peak

According to the Figure 13, especially for Çat Road, a quite long queue occurred in the morning peak. Çat Road has $60 \%$ of the total number of vehicles in the morning peak for Teknokent Junction. Therefore the longest queue length was expected to occur on Çat Road. However, this queue was totally discharged in green signal time according to the field observations. Other arms had approximately $20 \mathrm{~m}$ queue length and also were discharged in green signal time for morning peak. All arms had similar queue length in the evening peak except for the West Road. The arms that have the longest queue length were the arms which have public transportation vehicles.

After the proposed model was established in the study area, no traffic accident was observed for four months. This situation is the most important output for the established model.

\section{CONCLUSION}

- The final conclusions being reached can be summarized as follows:

- Signalized junction was planned and simulated by VISSIM for the junction

- Established right turn islands minimized the delay time.

- All arms were discharged in green signal period.

- Two signal programs were used due to different vehicle compositions for morning and evening peak.

- Similar periods of travel time were obtained depending on the morning and evening peak hours.
- No traffic accident was observed during the implementation of established model.

\section{ACKNOWLEDGEMENTS}

This work was supported by Research Fund of Erzincan University. Project Number: 12.01.17 and Research Fund of Atatürk University Project Number 2014/256. The authors would like to thank Atatürk University for the field applications.

\section{REFERENCES}

Abdel-Aty and Radwan AE, 2000. Modeling traffic accident occurrence and involvement. Accident Analysis \& Prevention, 32: 633-642.

Abdel-Aty M, Pande A and Hsia L, 2010. The concept of proactive traffic management for enhancing freeway safety and operation. ITE journal, 80: $34-41$.

Aw A and Rascle M, 2000. Resurrection of" second order" models of traffic flow. SIAM journal on applied mathematics, 60: 916-938.

Bell MC, Galatioto F, Giuffrè T and Tesoriere G, 2012. Novel application of red-light runner proneness theory within traffic microsimulation to an actual signal junction. Accident Analysis \& Prevention, 46: 26-36.

Brain F, Joel C, Yang O, 2007. Comparison of VISSIM Model to Other Widely Used Traffic Simulation and Analysis Programs. ITE Journal, 56: 67 .

Burghout W and Wahstedt J, 2007. Hybrid traffic simulation with adaptive signal control. Transportation Research Record, No:1999-20, 191197.

Cunto F and Saccomanno FF, 2008. Calibration and validation of simulated vehicle safety performance at signalized intersections. Accident Analysis \& Prevention, 40: 1171-1179.

Cunto FJC and Saccomanno FF, 2007. Microlevel traffic simulation method for assessing crash potential at intersections. In Transportation Research Board 86th Annual Meeting, 25 January 2007, Washington DC, United States.

De Dios Ortuzar J and Willumsen LG, 1994. Modelling transport. Fourth Edition, Wiley, UK, 586 p . 
El Esawey M and Sayed T, 2011. Unconventional USC intersection corridors: evaluation of potential implementation in Doha, Qatar. Journal of Advanced Transportation, 45: 38-53.

Fathy M and Siyal MY, 1997. Measuring traffic movements at junctions using image processing techniques. Pattern Recognition Letters, 18: 493-500.

Fellendorf M and Vortisch P, 2001. Validation of the microscopic traffic flow model VISSIM in different real-world situations. In Transportation Research Board 80th Annual Meeting, 7-11 Jan. 2001, Washington D.C.

Flaherty CA, 2000. Regulatory measures for traffic management. Traffic management and collision investigation, Mc hall, 450-464.

García A, Torres AJ, Romero MA and Moreno AT, 2011. Traffic microsimulation study to evaluate the effect of type and spacing of traffic calming devices on capacity. Procedia-Social and Behavioral Sciences, 16: 270-281.

Gladys F, 2009, Traffic management and transport demand management. The World Bank Distance Learning Course in Urban Planning, 450458.

Golias J, 1997. Effects of signalisation on four-arm urban junction safety. Accident Analysis \& Prevention, 29: 181-190.

Gomes G, May A and Horowitz R, 2004. A microsimulation model of a congested freeway using VISSIM. Proceeding Transportation Research Board 83 $3^{\text {rd }}$ Annual Meeting, 12-13 Jan. 2004, Washington D.C.

Guido G, Astarita V, Giofré V and Vitale A, 2011. Safety performance measures: a comparison between microsimulation and observational data. Procedia-Social and Behavioral Sciences, 20: 217-225.

Hollander Y and Liu R, 2008. The principles of calibrating traffic microsimulation models. Transportation, 35: 347-362.

Ištoka Otković I, Tollazzi T and Šraml M, 2013. Calibration of microsimulation traffic model using neural network approach. Expert systems with applications, 40: 5965-5974.
Laufer J, 2007. Freeway capacity, saturation flow and the car following behavioural algorithm of the VISSIM microsimulation software. In 30th Australasian Transport Research Forum, 25 April 2007, Melbourne, Australia.

Martínez MP, Garcia A and Moreno AT, 2011. Traffic Microsimulation Study to Evaluate Freeway Exit Ramps Capacity. Procedia-Social and Behavioral Sciences, 16: 139-150.

Park B and Schneeberger J, 2003. Evaluation of traffic signal timing optimization methods using a stochastic and microscopic simulation program. Research report UVACTS-5-0-4, Virginia Charlottesville, VA.

Peden M, 2004. World report on road traffic injury prevention. World Health Organization Geneva, Italy.

Saccomanno FF, Cunto F, Guido G and Vitale A 2008. Comparing safety at signalized intersections and roundabouts using simulated rearend conflicts. Transportation Research Record: Journal of the Transportation Research Board, 2078: 90-95.

Shankar K, Prasad C and Reddy T, 2013. Evaluation of Area Traffic Management Measures Using Microscopic Simulation Model. Procedia-Social and Behavioral Sciences, 104: 815-824.

Stevanovic J, Stevanovic A, Martin PT and Bauer T, 2008. Stochastic optimization of traffic control and transit priority settings in VISSIM. Transportation Research Part C: Emerging Technologies, 16: 332-349.

Sun DJ, Zhang L and Chen F, 2013. Comparative study on simulation performances of CORSIM and VISSIM for urban street network. Simulation Modelling Practice and Theory, 37: 18-29.

Truong LT, Sarvi M, Currie G and Garoni TM, 2015. Required traffic microsimulation runs for reliable multivariate performance estimates. Journal of Advanced Transportation, Published online in Wiley Online Library (wileyonlinelibrary.com). DOI: 10.1002/atr.1319. 